\title{
Otoliths-composed gelatin/sodium alginate scaffolds for bone regeneration
}

\author{
Daisy Pereira Valido ${ }^{1,2} \cdot$ Wilson Déda Gonçalves Júnior ${ }^{1,2} \cdot$ Maria Eliane de Andrade ${ }^{1,2} \cdot$ Allan Andrade Rezende ${ }^{1,2}$. \\ Felipe Mendes de Andrade de Carvalho ${ }^{1,2}$ • Renata de Lima ${ }^{3}$. Gabriela das Graças Gomes Trindade ${ }^{4}$ \\ Caio de Alcântara Campos ${ }^{4}$. Ana Maria Santos Oliveira ${ }^{4}$ • Eloísa Portugal Barros Silva Soares de Souza ${ }^{4}$. \\ Luiza Abrahão Frank ${ }^{5}$. Silvia Stanisçuaski Guterres ${ }^{5}$ • Eliana Midori Sussuchi ${ }^{4}$. Charlene Regina Santos Matos ${ }^{4}$. \\ André Polloni $^{1,2}$ - Adriano Antunes de Souza Araújo ${ }^{4}$. Francine Ferreira Padilha ${ }^{1,2}$ • Patrícia Severino ${ }^{1,2,6,7}$ (D) \\ Eliana Barbosa Souto ${ }^{8,9} \cdot$ Ricardo Luiz Cavalcanti de Albuquerque Júnior ${ }^{1,2}$
}

Published online: 8 September 2020

(C) Controlled Release Society 2020

\begin{abstract}
Evidence that otoliths, mineral-rich limestone concrescences present in the inner ear of bone fishes, can accelerate bone formation in vivo has been previously reported. The goal of this work was the development, characterization, and evaluation of the cytocompatibility of otoliths-incorporated sodium alginate and gelatin scaffolds. Cynoscion acoupa-derived otoliths were characterized by X-ray fluorescence spectrometry (FRX), particle size, free lime, and weight loss by calcination. Furthermore, otoliths were incorporated into sodium alginate (ALG/OTL-s) or gelatin (GEL/OTL-s) scaffolds, previously developed by freeze-drying. Then, the scaffolds were characterized by thermogravimetric analysis (TGA/DTG), differential scanning calorimetry (DSC), infrared spectroscopy with Fourier transform (FTIR), swelling tests, and scanning electron microscopy (SEM). Cytotoxicity assays were run against J774.G8 macrophages and MC3T3-E1 osteoblasts. Data obtained from TGA/DTG, DSC, and FTIR analyses confirmed the interaction between otoliths and the polymeric scaffolds. SEM showed the homogeneous porous 3D structure rich in otolith micro-fragments in both scaffolds. Swelling of the GEL/OTL-s $(63.54 \pm 3.0 \%)$ was greater than of ALG/ OTL-s $(13.36 \pm 9.9 \%)(p<0.001)$. The viability of J774.G8 macrophages treated with both scaffolds was statistically similar to the group treated with DMEM only $(p>0.05)$ and significantly higher than that treated with Triton-X $(p<0.01)$ at $72 \mathrm{~h}$. Both scaffolds showed approximately $100 \%$ growth of MC3T3-E1 osteoblasts by $24 \mathrm{~h}$, similarly to control $(p>0.05)$. However, by $48 \mathrm{~h}$, only ALG/OTL-s showed growth similar to control $(p>0.05)$, whereas GEL/OTL showed a significantly lower growth index $(p<0.05)$. In conclusion, the physicochemical profiles suggest proper interaction between the otoliths and the two developed polymeric 3D scaffolds. Moreover, both materials showed cytocompatibility with J774.G8 macrophages but the growth of MC3T3-E1 osteoblasts was higher when exposed to ALG/OTL-s. These data suggest that sodium alginate/otoliths scaffolds are potential biomaterials to be used in bone regeneration applications.
\end{abstract}

Keywords Otoliths $\cdot$ Bone regeneration $\cdot$ Tissue scaffolds $\cdot$ Tissue engineering

\section{Introduction}

Biodegradable osteoconductive polymeric scaffolds have been used in tissue engineering not only as a substrate for cell

Patrícia Severino

patricia_severino@itp.org.br; pseverino@bwh.harvard.edu

Ricardo Luiz Cavalcanti de Albuquerque Júnior ricardo.patologia@uol.com.br

Extended author information available on the last page of the article fixation and migration but also as a controlled delivery platform in bone regeneration processes [1].

Different polymers have been used for the development of scaffolds, including sodium alginate and gelatin. Sodium alginate is a hemostatic agent structurally similar to the extracellular matrix of living tissues, and has been widely used as a vehicle for controlled release of bioactive compounds in tissue regeneration [2-4]. Gelatin is a mixture of poly and oligopeptides derived from the partial hydrolysis of type I collagen, an important component of the skin, bones, and connective tissue, and can be easily modified to produce materials for controlled release of biominerals [5]. The versatility 
and diversity of biomaterials based on both polymers extend their applications beyond targeted drug delivery and are nowadays considered for wound dressings, contact lenses, and tissue engineering. Besides, these polymers also exhibit low antigenicity, high porosity porous allowing the accommodation of drugs for delivery and facilitating controlled release [6].

Otoliths are calcareous concretions found in the inner ear of teleostean fish (Teleostei), composed of a variety of inorganic compounds and high molecular weight collagenous proteins. The main inorganic constituents that have been found in this biomineral are calcium carbonate and some metallic elements ( $\mathrm{Sr}, \mathrm{Ba}, \mathrm{Mg}, \mathrm{Cd}, \mathrm{Co}, \mathrm{Cu}, \mathrm{Zn}, \mathrm{Na}, \mathrm{K}$ ) and nonmetals ( $\mathrm{Si}, \mathrm{P}, \mathrm{S}$, $\mathrm{B})$ [7]. It is based on a protein matrix composed mainly of otolin-1 and otolith-1 matrix protein [8]. The C-terminal domains of otolin-1 have high similarity to the same domains observed in type VIII and X of collagens [9], while the otolith1 matrix protein exhibits structural homology to melanotransferrin [10]. As these human proteins are closely related to the process of bone mineralization, it is suggested that otoliths could potentially work as a biomineral in bone neoformation. In addition, evidence that otoliths derived from Cynoscion acoupa carried in collagen/bacterial cellulose nanocomposites can induce bone neoformation has been previously reported [11].

The aim of this work was to develop, characterize, and evaluate the cytocompatibility of Cynoscion acoupa-derived otolith-incorporated scaffolds based on sodium alginate or gelatin polymeric matrices, searching for novel attractive biomaterials to be applied in bone regeneration.

\section{Materials and methods}

\section{Preparation and characterization of otoliths}

\section{Preparation of otoliths}

Otolith of Cynoscion acoupa (the fish was commercially purchased at the Antônio Franco Municipal market and the otolith was extracted) was grinded in a vibration-grinding mill (HERZOG HSM 100®) for $30 \mathrm{~s}$ and sifted in electromagnetic sieve agitator Bertel® until a whitish granulation powder with particle size $\leq 45 \mu \mathrm{m}$ mesh was obtained. The final material was placed in Petri dishes and sterilized under UV radiation for $25 \mathrm{~min}$, and then stored in a sterile metal box until further use.

\section{Determination of the otolith's pH}

Otolith was dispersed in distilled water $(1.0 / 100 \mathrm{~g} / \mathrm{mL})$, and the $\mathrm{pH}$ determined using $\mathrm{pH}$ meter Digimed®) DM22 (São Paulo, SP, Brazil) according to the manufacturer instructions.

\section{Determination of the weight loss by calcination}

The weight loss by calcination was determined gravimetrically on an analytical balance and Quimis ${ }^{\circledR}$ muffle furnace. Approximately $1.0 \mathrm{~g}$ of the dried sample was placed into the crucible $(P 2)$ and the solution was calcined at $950{ }^{\circ} \mathrm{C}$ for $1 \mathrm{~h}$ under oxidizing atmosphere. The sample was then cooled down in a desiccator. The sample (P3) was weighed and the percentage of mass loss by calcination was calculated using the following equation:

$\mathrm{PF}(\%)=\frac{(P 2-P 3)}{(P 2-P 1)} \times 100$

where $P 1$ is the initial weight of the crucible, $P 2$ is the weight of the crucible after the sample was added, and $P 3$ is the final weight of the crucible containing the reminiscent material after calcination.

\section{X-ray fluorescence spectrometer analysis}

Inorganic components of the calcinated sample were analyzed using a sequential wavelength dispersion X-ray fluorescence spectrometer (PANalytical BV-AXIOS-Advanced), with $4 \mathrm{~kW}$ X-ray tube, operated at $160 \mathrm{~mA}$, calibrated for semiquantitative analysis. Chemical compounds were quantified using software PANalytical SuperQ 4 Manager XRF. The percentage of calcium and calcium carbonate present in the sample was determined based on the molecular weight of the chemical compounds $\left(\mathrm{CaCO}_{3}=100, \mathrm{CaO}=56\right.$, and $\left.\mathrm{Ca}=40\right)$, using the following equations:

$\mathrm{CaCO}_{3}(\%)=\frac{\mathrm{CaO}(\%)}{0.56}$

$\mathrm{Ca}(\%)=\frac{\mathrm{CaO}(\%)}{0.71}$

\section{Determination of the free lime content}

Firstly, a suspension of otolith powder in ethylene glycol $(1: 30, \mathrm{~m} / \mathrm{v})$ was prepared and heated at $30{ }^{\circ} \mathrm{C}$ in a microwave oven for $30 \mathrm{~s}$. The suspension was homogenized and washed in $30 \mathrm{~mL}$ of ethylene glycol, filtrate and the filtered was titrated with $0.35 \mathrm{~mL}$ of $\mathrm{HCl}(0.1 \mathrm{M})$.

\section{Preparation and characterization of scaffolds}

\section{Preparation of the scaffolds}

Gelatin (Itá, Santa Catarina, Brazil) and sodium alginate (Protonal@RF6650, FMC Corporation, Philadelphia, PA, 
USA) powder $(1 \%, w / v)$ were dissolved in $100 \mathrm{~mL}$ of distilled water at $40{ }^{\circ} \mathrm{C}$ under magnetic stirring for $4 \mathrm{~h}$. Then, $1 \mathrm{~g}$ of otolith powder was slowly added into the solution, and the material was subjected to magnetic stirring for $1 \mathrm{~h}$. Subsequently, the obtained hydrogels were placed in plastic molds $(5 \mathrm{~mL})$ and frozen at $-20{ }^{\circ} \mathrm{C}$ for $24 \mathrm{~h}$. The frozen hydrogels were lyophilized at $-50{ }^{\circ} \mathrm{C}$ under $1.09 \mathrm{~Pa}$ for $48 \mathrm{~h}$ in a Freeze Dryer (Labconco FreeZone 4.5, USA). The dried samples of sodium alginate (ALG-s), gelatin (GEL-s), and sodium alginate and gelatin containing $1 \%$ otoliths (ALG/ OTL-s and GEL/OTL-s) were stored in sealed containers in a glass desiccator.

\section{Thermogravimetry and derived thermogravimetry}

Thermogravimetry (TG)/derived thermogravimetry (DTG) curves were obtained with a thermobalance model TGA-60/ TA-60WS (Shimadzu) in the temperature range $25-900{ }^{\circ} \mathrm{C}$, using platinum crucibles with $2.5 \mathrm{mg}$ of samples, under a dynamic nitrogen atmosphere $\left(100 \mathrm{~cm}^{3} / \mathrm{min}\right)$ and a heating rate of $10{ }^{\circ} \mathrm{C} / \mathrm{min}$.

\section{Differential scanning calorimetry}

Differential scanning calorimetry (DSC) curves were obtained in a DSC-60 cell (DSC-60 Plus series, Shimadzu, Brazil) using aluminum crucibles with about $2.5 \mathrm{mg}$ of samples, under a dynamic nitrogen atmosphere $50 \mathrm{~mL} / \mathrm{min}$ and heating rate of $10{ }^{\circ} \mathrm{C} / \mathrm{min}$ in the temperature range $25-500{ }^{\circ} \mathrm{C}$. The DSC cell was calibrated with indium $\left(\mathrm{m} . \mathrm{p} .156 .6^{\circ} \mathrm{C}\right.$; Hfus $=$ $28.54 \mathrm{~J} / \mathrm{g}$ ) and zinc (m.p. $419.6^{\circ} \mathrm{C}$ ).

\section{Fourier transform infrared spectroscopy}

The infrared absorption data of the scaffolds were obtained by attenuation reflectance method in the spectral range 4000$600 \mathrm{~cm}^{-1}$ in the range $4000-600 \mathrm{~cm}^{-1}$ in $\mathrm{KBr}$ pellets using the FTIR spectrometer (Varian 640-IR) at room temperature.

\section{Scanning electron microscopy}

Freeze-dried samples of the otoliths and scaffolds were sputter-coated with gold and their morphology was analyzed in a JEOL scanning microscope, JSM-6060 (Tokyo, Japan) operating at $7 \mathrm{kV}$.

\section{Swelling index}

The dried scaffolds ALG/OTL-s and GEL/OTL-s were accurately weighed and placed into $50 \mathrm{~mL}$ tubes containing $45 \mathrm{~mL}$ of phosphate-buffered saline (PBS) solution ( $\mathrm{pH} \mathrm{7.4)} \mathrm{at} 37^{\circ} \mathrm{C}$. At predetermined time intervals $(0,3,8,15,30,45$, and $60 \mathrm{~min}$ ), the swollen scaffolds were wiped with soft paper tissue and weighed again. All the procedures were performed in triplicate and the degree of swelling for all samples at each time is calculated using the following equation:

$S(\%)=\frac{W_{d}-W_{w}}{W_{d}} \times 100$

where $W_{d}$ and $W_{w}$ are the weights of dry and swollen scaffolds, respectively.

\section{Cell viability in macrophage cell culture study J774.G8}

Cells (ATCC CVCL_HA26, Mouse BALB/c monocyte macrophage, Merck, Brazil) were maintained in polystyrene culture flasks containing DMEM culture medium supplemented with $10 \% \mathrm{FBS}$ and cultured at $37{ }^{\circ} \mathrm{C}$ and $5 \% \mathrm{CO}_{2}$. For the cytotoxic assays, 24-h cultured macrophages were washed twice with culture medium and then released from the culture flasks. Three hours before the incubation time, resazurin diluted in PBS at $0.15 \mathrm{mg} \mathrm{mL}^{-1}$ was added. Then, a suspension of $10^{6}$ cells $\mathrm{mL}^{-1}$ was prepared, from which $100 \mu \mathrm{L}$ was transferred to a 96-well microplate. As a positive control, Triton-X 100 was used, and as a negative control, cells were used with DMEM medium (Dulbecco's Modified Eagle's Medium - Gibco®). After $2 \mathrm{~h}$ of incubation, cell cultures were subjected to $10 \mathrm{mg} \mathrm{mL}^{-1}$ of each scaffold (ALG/OTL-s and GEL/OTL-s) and incubated for an additional $72 \mathrm{~h}$. The minimal cytotoxic concentration (MCC) was determined by the MTT (3-(4,5-dimethylthiazol2-yl)-2,5-diphenyltetrazolium bromide) tetrazolium reduction assay. Absorbance was measured at $570 \mathrm{~nm}$ and $595 \mathrm{~nm}$ in a SpectraMax M5 spectrophotometer (Molecular Devices, CA) according to the following equation (AL-NASIRY et al., 2007):

$\operatorname{RR}(\%)=\frac{(\varepsilon \operatorname{ox} \lambda 595 \times \mathrm{A} \lambda 570)-(\varepsilon \operatorname{ox} \lambda 570 \times \mathrm{A} \lambda 595)}{\left(\operatorname{\varepsilon red} \lambda 570 \times \mathrm{A}^{\prime} \lambda 595\right)-\left(\varepsilon \operatorname{red} \lambda 595 \times \mathrm{A}^{\prime} \lambda 570\right)}$

where RR (\%) is the percentage of resazurin reduction, and $\varepsilon 0 x \lambda$ and $\varepsilon$ red $\lambda$ are constants of the molar extinction coefficient at wavelengths of $595 \mathrm{~nm}$ and $570 \mathrm{~nm}$, in the oxidized and reduced forms. $\mathrm{A} \lambda$ represents the absorbance values obtained on the wells, and $A \lambda^{\prime}$ the reference absorbance in the wells with no cell. These tests were performed in triplicate for each sample.

\section{Cell viability in MC3T3-E1, Subclone 14 (bone calvaria) osteoblastic cells}

The osteoblastic cell line of MC3T3-E1 Subclone 14 mice (ATCC CRL-2594, Mouse C57BL/6 bone calvaria, Merck, Brazil) was used in this assay. Cells were initially plated (Time $0 \mathrm{~h}$ ) at a concentration of $1 \times 10^{5}$ cells/well in a 24 well plate which were incubated at $37{ }^{\circ} \mathrm{C}-5 \% \mathrm{CO}_{2}$ using Alpha medium Minimum Essential Medium with 
ribonucleosides, deoxyribonucleosides, $2 \mathrm{mM}$ L glutamine, and $1 \mathrm{mM}$ sodium pyruvate, without ascorbic acid, plus fetal bovine serum to a final concentration of $10 \%$. After $24 \mathrm{~h}$ and total adhesion of the cells, they were placed in contact with the material for 24 to $48 \mathrm{~h}$. After the treatment period, the samples were removed from the cultures and the cells were washed with PBS, trypsinized, and counted using the Image Cytometry technique. An aqueous solution of $10 \mathrm{mg} / \mathrm{mL}$ otoliths was used as a control.

\section{Statistical analysis}

Data analyses were performed using GraphPad Prism 5.0 (GraphPad Prism Software Ins., San Diego, CA, USA). Data were subjected to normality distribution analysis using the Shapiro-Wilk test. Then, data obtained in the swelling index were analyzed using Student's $T$ test. Cytotoxicity analysis data on macrophages J774.G8 were analyzed by one-way ANOVA, whereas data on the viability of MC3T3-E1 osteoblasts were analyzed by two-way ANOVA. Both tests were followed by Tukey's post hoc multiple comparison test. All values were expressed as mean \pm standard deviation of the mean (SD) and differences between means were considered significant when the " $p$ " value was less than 0.05 .

\section{Results and discussion}

The prepared otolith sample exhibited as a whitish fine granulation powder $(\leq 45.0 \mu \mathrm{m})$, with $\mathrm{pH} 8.8$. Tissue-nonspecific alkaline phosphatase (TNAP) is an enzyme that hydrolyzes pyrophosphate and provides inorganic phosphate to promote mineralization, which works at alkaline medium ( $\mathrm{pH}$ between 8 and 11) [12]. Moreover, alkaline $\mathrm{pH}$ was shown to increase osteoblasts viability in vitro and induce the development of cell properties typically observed in mature osteoblasts, such as the expression of late osteoblastic transcription factors and the ability to mineralize [13]. It is thus suggested that the otolith preparation $\mathrm{pH}$ could positively interfere with the potential osteoinductive/conductive activity of scaffolds.

The percentage of otolith grinding retention in the sieve was $0.4 \%$, with $99.6 \%$ of particles with a particle size $\leq$ $45 \mu \mathrm{m}$, which is consistent with a very homogeneous granulometric behavior. It is likely that the large surface area of the otolith microparticles could promote fast dissolution due to the greater surface area exposed to the biological environment, allowing the chemical interaction between the biomaterial and the new formed bone, and accelerate the formation and the growth of the biologically active apatite layer [14]. Furthermore, recent reports have suggested that larger sized hydroxyapatite particles $(20-100 \mu \mathrm{m})$ generate a less prolonged inflammatory response compared with smaller ones, which suggest that incorporation of larger sized particles into biomaterials scaffolds might prove beneficial in promoting a tissue regenerative microenvironment upon implantation [15].

The mass loss by calcination analysis revealed that the otolith preparation had a mass loss of $47.4 \%$, compatible with $\mathrm{CO}_{2}$ release from calcite $\left(\mathrm{CaCO}_{3}\right)$ calcination, and $0.08 \%$ relative to water loss. These data suggest low organic content and confirm the high concentration of inorganic compounds in the sample. After calcination, FRX showed the presence of calcium oxide as the major element in the composition of otoliths $(52 \%)$. However, as the calcination procedures led to about $47.4 \%$ of mass loss due to $\mathrm{CO}_{2}$ release, it is possible to infer that there was $92.85 \%$ of calcium carbonate. The other components were represented by some metal $(\mathrm{Sr}, \mathrm{Ba}, \mathrm{Mg}, \mathrm{Cd}, \mathrm{Co}$, $\mathrm{Cu}, \mathrm{Zn}, \mathrm{Na}, \mathrm{K}$ ) and nonmetal elements ( $\mathrm{Si}, \mathrm{P}, \mathrm{S}, \mathrm{B})$. The high content of calcium carbonate in the chemical composition of otoliths has also been previously described by Izzo et al. [7]. In addition, otolith preparation presented $0.09 \%$ free lime (expressed as free $\mathrm{CaO}$ ) available to interact with water molecules. Calcium oxide is a very reactive compound that interacts with water molecules causing a hydration reaction, incorporating hydroxyl ions $\left(\mathrm{OH}^{-}\right)$into their crystalline structure to form transforming calcium hydroxide $\left[\mathrm{Ca}(\mathrm{OH})_{2}\right]$. The dissolution of calcium hydroxide offers an early abundant supply of calcium and hydroxyl calcium [16], that can participate in the formation of pure hydroxyapatite crystals, the major component of the inorganic mineral phase of the bone matrix [17]. The chemical composition of otoliths may thus possible favor bone neoformation, since the higher the content of carbonate in a biomineral, the greater the osteoconductivity [18].

The thermogravimetric (TG/DTG) and DSC curves of otoliths, ALG/OTL-s, and GEL/OTL-s scaffolds are shown in Fig. 1 and Table 1. The thermogravimetric curve of the otoliths shows the thermal stability of the mineral in the range of 25 to $600{ }^{\circ} \mathrm{C}$. Then, a mass loss event of $35.87 \%$ (Tpeak $=$ $650{ }^{\circ} \mathrm{C}$ ) occurred, probably related to the degradation of the calcium carbonate molecules present in the chemical composition of the otoliths. Supporting our findings, the decomposition temperature of the calcium carbonate has been demonstrated to be over $600{ }^{\circ} \mathrm{C}$ [19]. Three stages of mass loss were observed in the TG curve of ALG-s. There was a thermal event around 25 to $200{ }^{\circ} \mathrm{C}$, with $10.56 \%$ of mass loss, corresponding to the dehydration of the sample relative to the residual moisture of the polysaccharide and water more internally bound to the alginate structure. Between 200 and $500{ }^{\circ} \mathrm{C}$, there was a mass loss of $23.21 \%$, probably due to degradation of anhydrous sodium alginate and formation of sodium carbonate $\left(\mathrm{Na}_{2} \mathrm{CO}_{3}\right)$, whereas between 500 and $800{ }^{\circ} \mathrm{C}\left(\right.$ Tpeak $\left.=566{ }^{\circ} \mathrm{C}\right)$, there was a mass loss of $29.04 \%$, associated with the decomposition of sodium carbonate in sodium oxide $\left(\mathrm{NaO}_{2}\right)$ and release of carbon dioxide $\left(\mathrm{CO}_{2}\right)$. The residual mass was $37.19 \%$ of the initial mass. Similar thermal events regarding the thermal analysis of sodium 
alginate have been previously reported [20]. ALG/OTL-s, similar to ALG-s, also presented the same thermal events, represented by dehydration $\left(25\right.$ to $200{ }^{\circ} \mathrm{C}$, with $11.84 \%$ of mass loss), decomposition $\left(200\right.$ and $500^{\circ} \mathrm{C}$, it was noticed a loss of mass of $27.60 \%$ ), and degradation (between 500 and $800{ }^{\circ} \mathrm{C}$, with loss of mass of $13.49 \%$ ). The residual mass was $47.07 \%$ of the initial mass.

GEL-s depicted two thermal events, one occurring at approximately 200 to $500{ }^{\circ} \mathrm{C}$, with a mass loss of $54.96 \%$, related to protein chain breakdown (helical structure) and rupture of the peptide bonds, and another at 500 to $800{ }^{\circ} \mathrm{C}$ $\left(\right.$ Tpeak $\left.=486.14{ }^{\circ} \mathrm{C}\right)$, resulting in a small mass loss of $3.73 \%$. The final residue was $42.31 \%$ of the initial mass. Supporting our findings, the thermal decomposition of gelatin has been reported to occur between 25 and $250{ }^{\circ} \mathrm{C}$ [21]. However, the GEL/OTL-s presented three stages of mass loss, the first occurring between 25 and $200{ }^{\circ} \mathrm{C}$ (loss of $7.75 \%$ ), attributed to loss of adsorbed and structural water, the second between 200 and $500{ }^{\circ} \mathrm{C}$ (loss of $44.73 \%$ ), and the last one between 500 and $800{ }^{\circ} \mathrm{C}$ (typical $=581.70{ }^{\circ} \mathrm{C}$ and loss of $27.14 \%$ ), related to the degradation of the sample and to the final residue, with approximately $20.38 \%$ of the initial mass. The changes in mass loss percentage variations and degradation temperature peaks between the scaffolds of ALG $\left(\right.$ Tpeak $\left.=566.16{ }^{\circ} \mathrm{C}\right)$ and ALG/OTL $\left(\right.$ Tpeak $\left.=702.74{ }^{\circ} \mathrm{C}\right)$ and between scaffolds of GEL-s (Tico $=486.14{ }^{\circ} \mathrm{C}$ ) and GEL/OTL-s $\left(\right.$ Tico $=581.70^{\circ} \mathrm{C}$ ) suggest the interaction of otoliths with the polymer matrices, increasing their thermal stability.

The DSC curves of otoliths, ALG-s, GEL-s, ALG/OTL-s, and GEL/OTL-s are shown in Fig. 2 and Table 2. The otoliths presented thermal stability in the range of $25^{\circ}$ to $500^{\circ} \mathrm{C}$ without changes in their physical state, in agreement with the data observed in TG. ALG-s presented an endothermic peak (Tpeak $=89.2{ }^{\circ} \mathrm{C}$ ) characteristic of dehydration of the alginate polymer [20]. An exothermic peak was observed between 200 and $270{ }^{\circ} \mathrm{C}$ (Tpeak $\left.=245^{\circ} \mathrm{C}\right)$, likely related to the oxidative degradation of the glycosidic ring in the alginate structure [22]. A last exothermic peak was observed at $441.2^{\circ} \mathrm{C}$, probably representing $\mathrm{CO}_{2}$ release, which could also be observed in the TG curve. ALG/OTL-s decreased the intensity and temperature of the characteristic peaks of the polymer (typical $=71.3{ }^{\circ} \mathrm{C}, 244.4^{\circ} \mathrm{C}$, and $437.2^{\circ} \mathrm{C}$ ), which is suggestive of an interaction between otoliths and the polymer GEL-s presented an endothermic peak in the temperature range between 25 and $150{ }^{\circ} \mathrm{C}$ characteristic of vaporization (Tpeak = $101.72{ }^{\circ} \mathrm{C}$ ) and consequent dehydration of the polymer. In the temperature range between 150 and $300^{\circ} \mathrm{C}$, an exothermic event $\left(\right.$ Tpeak $=176.49^{\circ} \mathrm{C}$ ) was observed, which may be associated to the oxidative thermo-degradation process of the polymer due to protein chain breakdown (helical structure) and peptide bond rupture [20]. In the range of $300^{\circ}$ to $400{ }^{\circ} \mathrm{C}$ (Tpeak $\left.=431.7^{\circ} \mathrm{C}\right)$, probably the sublimation of the polymer and, therefore, pyrolysis decomposition occurs. GEL/OTL-s showed a decrease in the intensity and temperature of the peak characteristic GEL-s (Tpeak $=71.3{ }^{\circ} \mathrm{C}$ and $\left.450.4{ }^{\circ} \mathrm{C}\right)$. Since this DSC curve has similarities with that obtained for the otoliths, the incorporation of the biomineral to the protein matrix can be suggested.

FTIR profiles and elemental analyses were used to investigate the coexistence, nucleation, and deposition of the inorganic compound of the otoliths within the various organic matrices. The FTIR spectra of OTL, ALG-s, and ALG-OTL-s are shown in Fig. 3. OTL FTIR spectral data are characteristic of carbonate groups $\left(\mathrm{CO}_{3}^{-2}\right)$, with absorption bands located at 875 and $1400-1500 \mathrm{~cm}^{-1}$. Intense bands can be observed at $1420 \mathrm{~cm}^{-1}$, representing the anti-symmetrical stretching of the carbonyl of the carboxylate ion $(\mathrm{C}=\mathrm{O})$; at $858 \mathrm{~cm}^{-1}$, related to the angular deformation of the $\mathrm{CO}_{3}$ group; and at $708 \mathrm{~cm}^{-1}$, characteristic of angular deformations in the $\mathrm{O}=\mathrm{C}=\mathrm{O}$ plane characteristic of $\mathrm{CaCO}_{3}$ present in its structure in the form of aragonite [23]. A band was observed in $1080 \mathrm{~cm}^{-1}$, related to the symmetrical stretch $\mathrm{C}=\mathrm{O}$, similar to the corresponding patterns of $\mathrm{CaCO}_{3}$ in calcite forms $\left(1080 \mathrm{~cm}^{-1}\right)$ [24], and to the $\mathrm{PO}_{4}{ }^{3-}$ found in calcium phosphate [25]. The absorption band near $2520 \mathrm{~cm}^{-1}$ indicated the presence of the $\mathrm{HCO}_{3}$ radical in the material and the large band in the region of 3300 to $3400 \mathrm{~cm}^{-1}$ referring to the stretching of the $\mathrm{OH}$ group can be attributed to the presence of water molecules from the moisture in the sample, as previously demonstrated by De Souza et al. [24].

Table 1 Percentage of mass loss and degradation temperatures of the samples obtained by TGA/DTG from otoliths (OTL), ALG-s, GEL-s, ALG/OTLs, and GEL/OTL-s

\begin{tabular}{lllrl}
\hline Samples & $\begin{array}{l}\text { 1st stage }(\%) \\
\left(25-200{ }^{\circ} \mathrm{C}\right)\end{array}$ & $\begin{array}{l}\text { 2nd stage }(\%) \\
\left(200-500{ }^{\circ} \mathrm{C}\right)\end{array}$ & $\begin{array}{l}\text { 3rd stage }(\%) \\
\left(500-800{ }^{\circ} \mathrm{C}\right)\end{array}$ & $\begin{array}{c}\text { Degradation }\left({ }^{\circ} \mathrm{C}\right) \\
\text { OTL }\end{array}$ \\
\hline GEL-s & - & - & $35.87 \pm 2.5$ & 650 \\
GEL/OTL-s & - & $54.96 \pm 2.6$ & $3.73 \pm 0.9$ & 486.14 \\
ALG-s & $7.75 \pm 0.6$ & $44.73 \pm 1.1$ & $27.14 \pm 1.2$ & 581.70 \\
ALG/OTL-s & $10.56 \pm 0.5$ & $23.21 \pm 2.9$ & $29.04 \pm 0.3$ & 566.16 \\
\hline
\end{tabular}




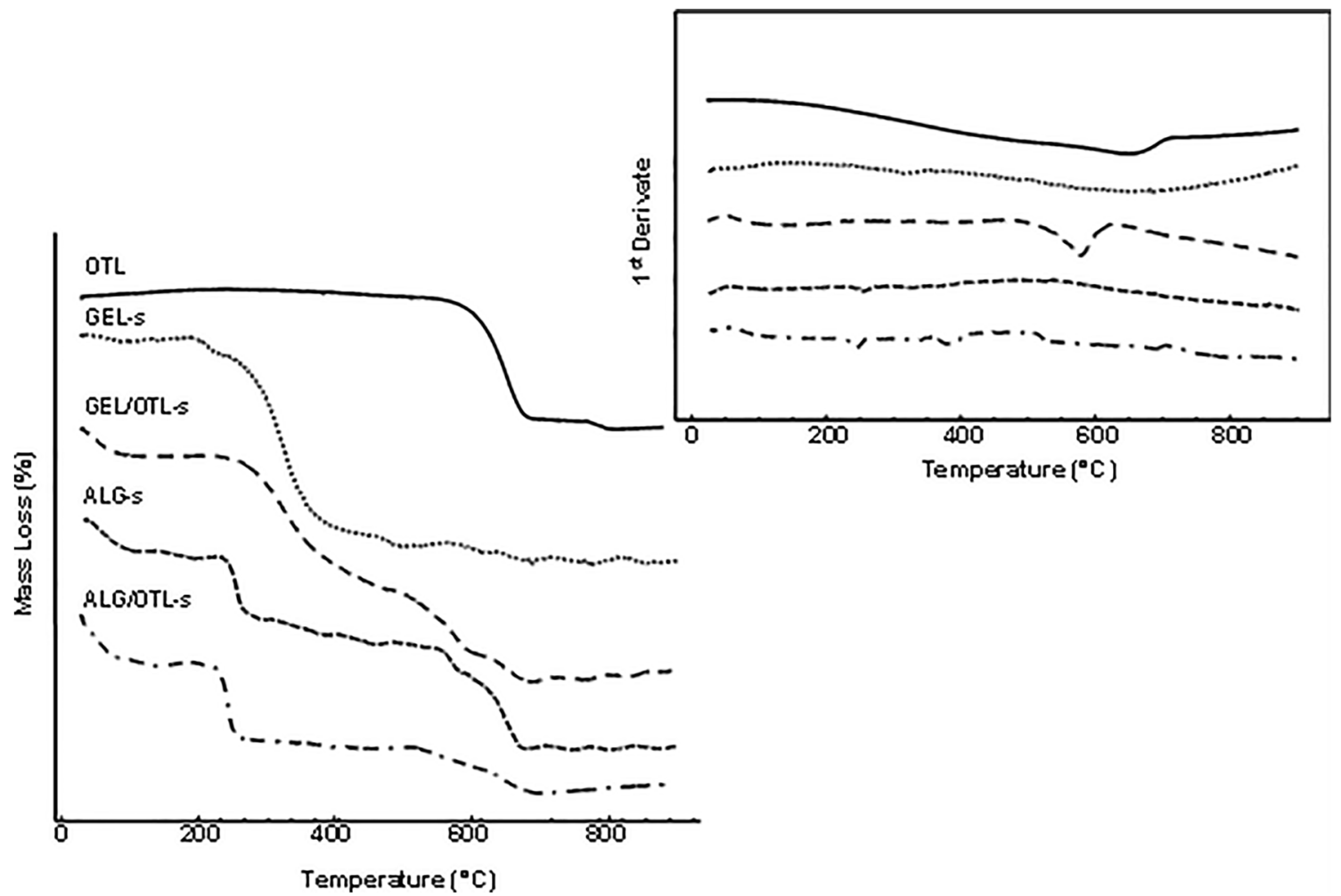

Fig. 1 TGA/DTG curve demonstrating the percentage of mass loss vs. temperature

Characteristic bands of carboxylic acids were observed in the spectrum of ALG-s, located between 2800 and $3000 \mathrm{~cm}^{-1}$, related to $\mathrm{CH}_{2}$ or $\mathrm{C}-\mathrm{H}$ groups, between 2500 and $2300 \mathrm{~cm}^{-1}$, related to the group $\mathrm{S}=\mathrm{O}$, between 1771 and $1537 \mathrm{~cm}^{-1}$, related to the $\mathrm{C}=\mathrm{O}$ of the carboxylic acid groups, between 1416 and $1304 \mathrm{~cm}^{-1}$ concerning the axial deformation of the $\mathrm{C}=\mathrm{O}$ of the carboxylic acids, and at $1040 \mathrm{~cm}^{-1}$ regarding the absorption of the ethers. Similar data concerning the alginate spectrum was previously reported by Mirzaei et al. [26].

ALG/OTL-s showed a reduction in the band corresponding to the $\mathrm{O}-\mathrm{H}$ groups and in the bands between 950 and $640 \mathrm{~cm}^{-1}$ corresponding to the $\mathrm{C}-\mathrm{H}$ and $\mathrm{C}-\mathrm{C}$ bonds of the alginate, probably due to auto-oxidation [26]. There was displacement in the bands between 1400 and $1450 \mathrm{~cm}^{-1}$, and reduction in the intensity of the bands between 1771 and

Table 2 Thermal events obtained of the DSC curves from otoliths (OTL), ALG-s, GEL-s, ALG/OTL-s, and GEL/OTL-s

\begin{tabular}{llll}
\hline Samples & 1st stage $(\%)$ & 2nd stage $(\%)$ & 3rd stage $(\%)$ \\
\hline OTL & - & - & - \\
& $\left(25-150{ }^{\circ} \mathrm{C}\right)$ & $\left(150-270{ }^{\circ} \mathrm{C}\right)$ & $\left(270-450{ }^{\circ} \mathrm{C}\right)$ \\
ALG-s & 89.2 & 245 & 441.2 \\
ALG/OTL-s & 71.3 & 244.4 & 437.2 \\
& $\left(25-150{ }^{\circ} \mathrm{C}\right)$ & $\left(150-300{ }^{\circ} \mathrm{C}\right)$ & $\left(300-460{ }^{\circ} \mathrm{C}\right)$ \\
GEL-s & 101.72 & 176.4 & 431.7 \\
GEL/OTL-s & 71.3 & & 450.4 \\
\hline
\end{tabular}

$1304 \mathrm{~cm}^{-1}$, which are related to $\mathrm{C}=\mathrm{O}$ of the carboxylic acid groups. These changes probably occurred due to the substitution of alginate sodium by the calcium of the otoliths.

When a carboxylic acid is converted to carboxylate, the generated carboxylate ion has a negative charge equally distributed over two oxygen atoms, and the $\mathrm{C}=\mathrm{O}$ and $\mathrm{C}-\mathrm{O}$ bonds are replaced by two equivalent $\mathrm{C}-\mathrm{O}$ bonds. Thus, the carboxylate ion has two characteristic bands, one of which is intense, resulting from the asymmetric axial deformation of the $\mathrm{C}-\mathrm{O}$

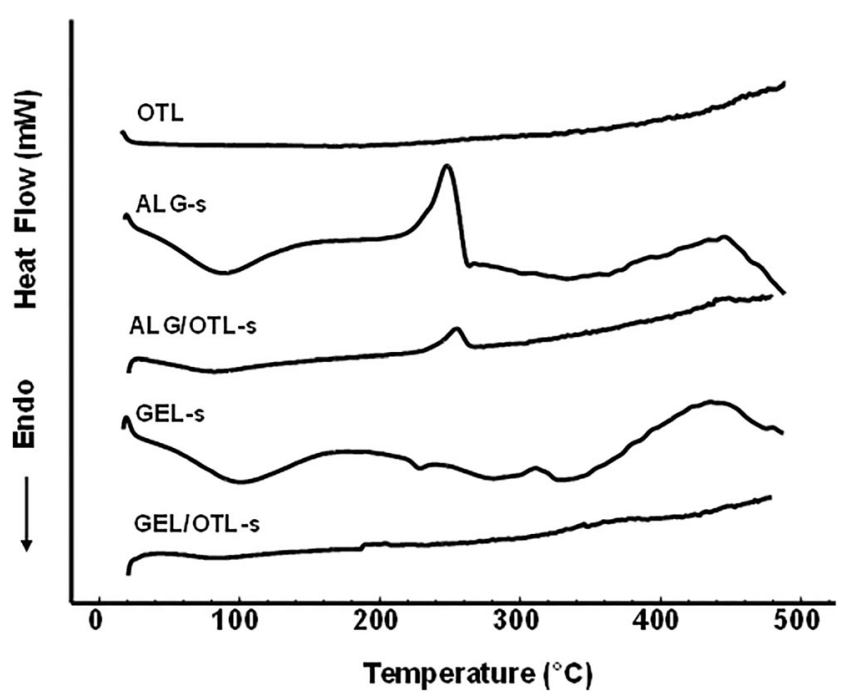

Fig. 2 DSC curve demonstrating the changes in the physical status of the material vs. temperature 

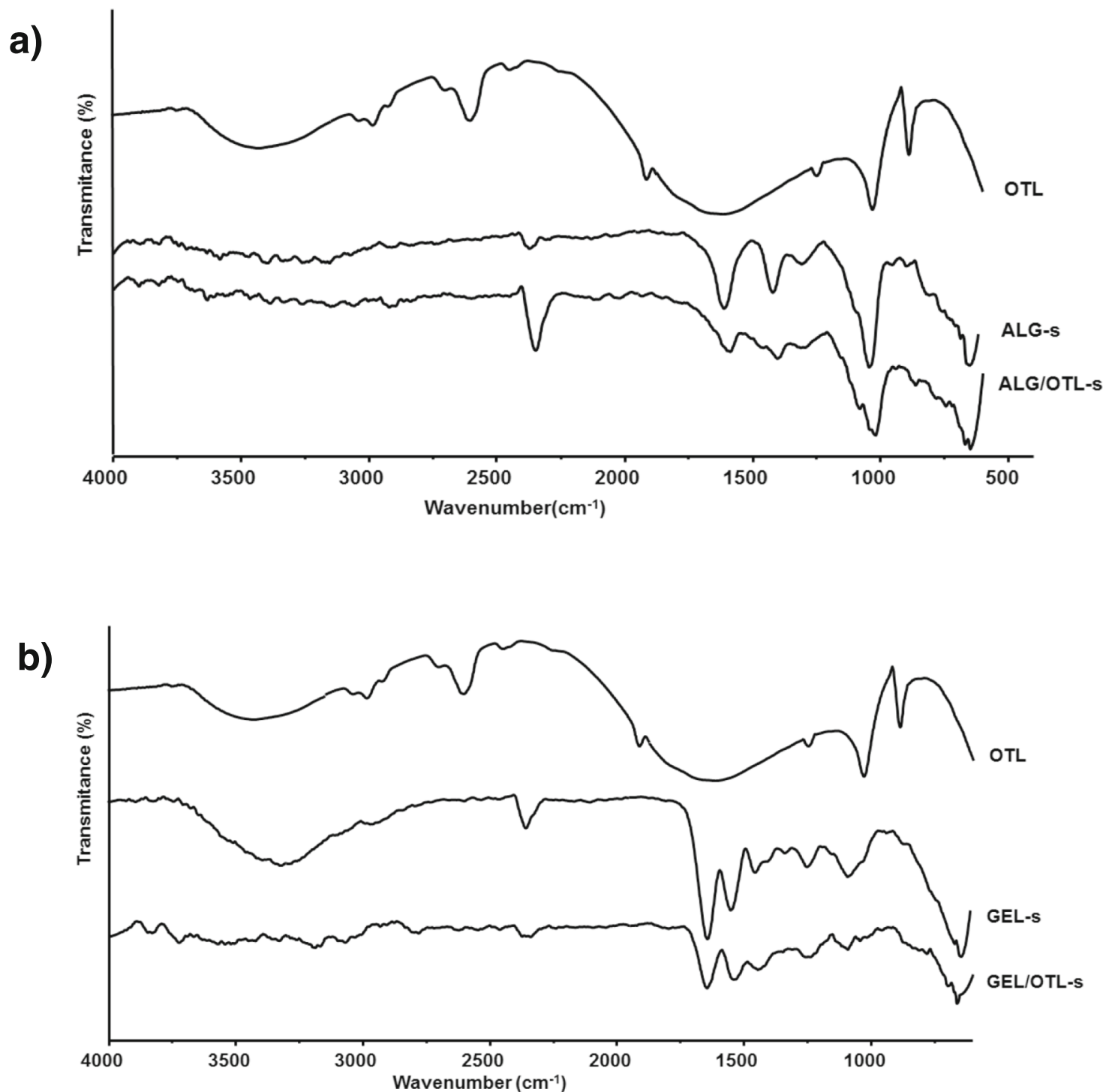

Fig. 3 FTIR spectra of a otoliths and scaffolds of sodium alginate (ALG-s) and sodium alginate containing otoliths (ALG/OTL-s); and $\mathbf{b}$ otoliths and scaffolds of gelatin (GEL-s) and gelatin containing otoliths (GEL/OTL-s)

bond and appears between 1650 and $1550 \mathrm{~cm}^{-1}$. The other, weaker, is observed around $1400 \mathrm{~cm}^{-1}$ and results from the symmetrical axial deformation of the $\mathrm{C}-\mathrm{O}$ bond. In addition, the band displacement and intensity increase between 2500 and $2000 \mathrm{~cm}^{-1}$, characteristic of the stretching of the alkynes and nitriles groups $(-\mathrm{C} \equiv \mathrm{C}-, \mathrm{C} \equiv \mathrm{N})$ was identified. The set of these spectral changes seems to suggest the interaction between the otoliths and the alginate polymer.

GEL-s showed bands between 3513 and $3123 \mathrm{~cm}^{-1}$ referring to the flexural vibration of $\mathrm{N}-\mathrm{H}$ and another between 2988 and $2828 \mathrm{~cm}^{-1}$ referring to $\mathrm{O}-\mathrm{H}$ chelates. Bands at 1639 and $1538 \mathrm{~cm}^{-1}$ related to the amide bonds, referring to the amide bands I and II, respectively, were attributed to the stretching vibrations of the $\mathrm{C}=\mathrm{O}$ bond and as a result of the coupling of the $\mathrm{N}-\mathrm{H}$ flexion in the plane to the amide I and stretching the $\mathrm{C}-\mathrm{N}$ bonds to the amide II, the band at
$1238 \mathrm{~cm}^{-1}$ was caused by the vibration of the $\mathrm{CH}_{2}$ oscillation relating to the amide III. A band corresponding to the $\mathrm{NH}_{2}$ groups was observed at $1540 \mathrm{~cm}^{-1}$, and one related to the axial deformations of $\mathrm{C}=\mathrm{O}$ groups of carboxylic acids was evidenced between 1183 and $1003 \mathrm{~cm}^{-1}$. Similar results were also demonstrated by Poddar et al. [27]. GEL/OTL-s showed the disappearance of the bands referring to the $\mathrm{N}-\mathrm{H}$ groups and the $\mathrm{O}-\mathrm{H}$ chelate groups. Furthermore, reduction of the intensity of the bands related to the axial deformations of the $\mathrm{C}=\mathrm{O}$ groups of carboxylic acids was also observed. Therefore, the interaction between the components of the gelatin molecules and otoliths can be suggested.

The swelling behavior of the scaffolds can be seen in Fig. 4. A significant increase in the mass of GEL/OTL-s $(p<0.001)$ and ALG/OTL-s $(p<0.05)$ was observed at the end of the experiment, in relation to their initial dry mass. 


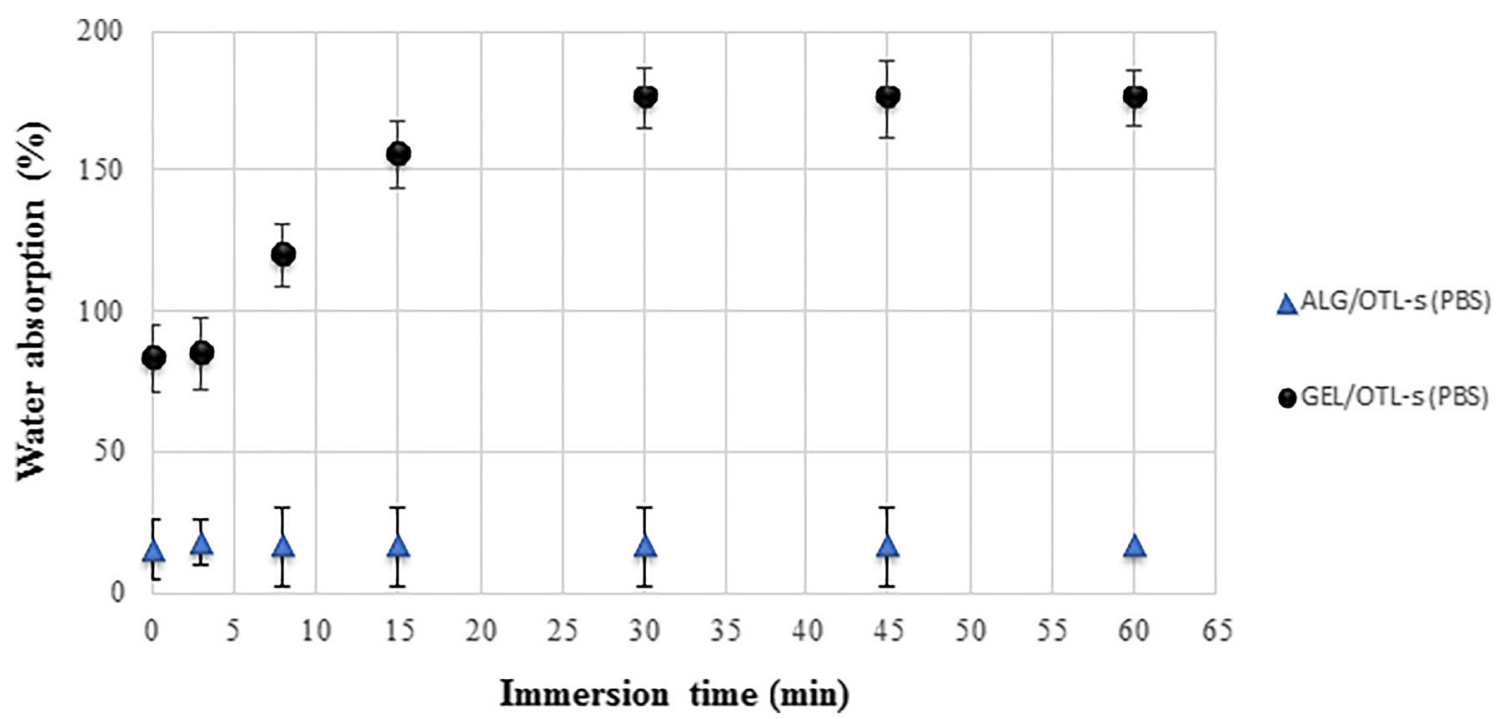

Fig. 4 Swelling behavior of otolith-incorporated gelatin-based (GEL/OTL-s) and sodium alginate-based (ALG/OTL-s) scaffolds immersed in PBS over time

However, swelling of the GEL/OTL-s scaffolds was significantly greater than the ALG/OTL-s $(p<0.001)$. Functional groups present on the otoliths interact with the polymer chains of gelatin and alginate, thereby forming hydrogen bonds. For this reason, it is possible to suggest that the intense swelling of the GEL/OTL-s $(63.54 \pm 3.0 \%$ in relation to the initial mass) compared with ALG/OTL-s $(13.36 \pm 9.9 \%)(p<0.001)$ probably occurred due to the penetration of liquid into the scaffold pores and interaction of the free hydroxyl with water molecules by hydrogen interactions [28]. On the other hand, ALG/ OTL-s, presented a lower swelling, possibly because the presence of calcium complexed with the alginate molecule, through the anionic domains of alginate interacting with the cationic domains of the otoliths, made the reactive hydrophilic sites unavailable for interaction with the water molecules [27]. As GEL/OTL scaffolds showed greater swelling, this biomaterial could retain greater amounts of organic fluids, maintaining its shape and providing a stable framework for the formation of clots (PODDAR et 2019). However, the anatomical site of implantation of the scaffolds is critical to analyze whether large swelling is beneficial or not, as long as largely swollen scaffolds could compress the surrounding healthy tissues and impair bone repair (SHIMOJO et al., 2016). Therefore, as ALG/OTL-S showed to be able to absorb relatively great amounts of blood fluid without presenting excessive swelling, they should be considered more suitable to be used as potential biomaterials in anatomical sites limited by rigid walls, such as bone cavities.

Both materials formed three-dimensional porous structures typically observed in scaffolds [27]. GEL-s exhibited numerous and more regular pores with approximately 100 to $150 \mu \mathrm{m}$ diameters (Fig. 5a and b), which is in agreement with previous reports by Verma et al. [29]. ALG-s, in turn, formed pores ranging from 200 to $350 \mu \mathrm{m}$, with thicker walls (Fig. 5c and d), data also observed in previous studies described by Pan et al. [30]. A large surface area favors cell attachment and growth, whereas a large volume of pores is required to accommodate the cell content necessary for tissue repair. In turn, pore continuity within a synthetic matrix allows the transport of materials and cell migration [31]. Moreover, in bone tissue repair, at least $90 \%$ porosity and $100-500 \mu \mathrm{m}$ pore size are required for proper cell diffusion and adhesion, and development of a capillary network to provide blood supply [32]. The high porosity also minimizes the amount of polymer to be implanted, and allows the transfer of metabolic residues by nutrients, facilitating cell growth in the matrices [33].

Otoliths were presented as rectangular, polyhedral, or cuboid crystals, with irregular and rough surface and diameter ranging from 5 to $45 \mu \mathrm{m}$ (Fig. 6a and b). After their incorporation into gelatin (GEL/OTL-s, Fig. 6c and d) and alginate (ALG/OTL-s, Fig. 6e and f), the micro-fragments of otoliths were seen as small crystals of variable diameter homogeneously distributed along the walls of the 3D structure of both scaffolds. In addition to the homogeneity in the distribution of otoliths in GEL/OTL-s and ALG/OTL-s, no voids or defects of the structure were observed within the walls. Such characteristics allow the composite to be used in the development of three-dimensional porous scaffolds for bone regeneration since empty spaces between the fibers hinder the integration with the host tissue and large interfibrillar spaces impair blood vessels growth, cell migration, and nutrient transport throughout the scaffold [34].

In the cytotoxicity assay using J774.G8 cells, GEL/OTL-s and ALG/OTL-s had a significantly higher rate of cell turnover than Triton-x (positive control) $(p<0.001)$, close to $100 \%$. These data suggest that nanocomposites that did not present a cytotoxic effect are shown in Fig. 7. Surprisingly, cell viability in ALG/OTL-s was lower than in DMEM 
Fig. 5 SEM photomicrographs of cross sections of the pore surfaces of scaffolds 3D scaffolds observed under SEM. a, b Scaffolds of gelatin presenting numerous and regular pores limited by thin walls. c, d Scaffolds of sodium alginate exhibiting larger pores with thicker walls
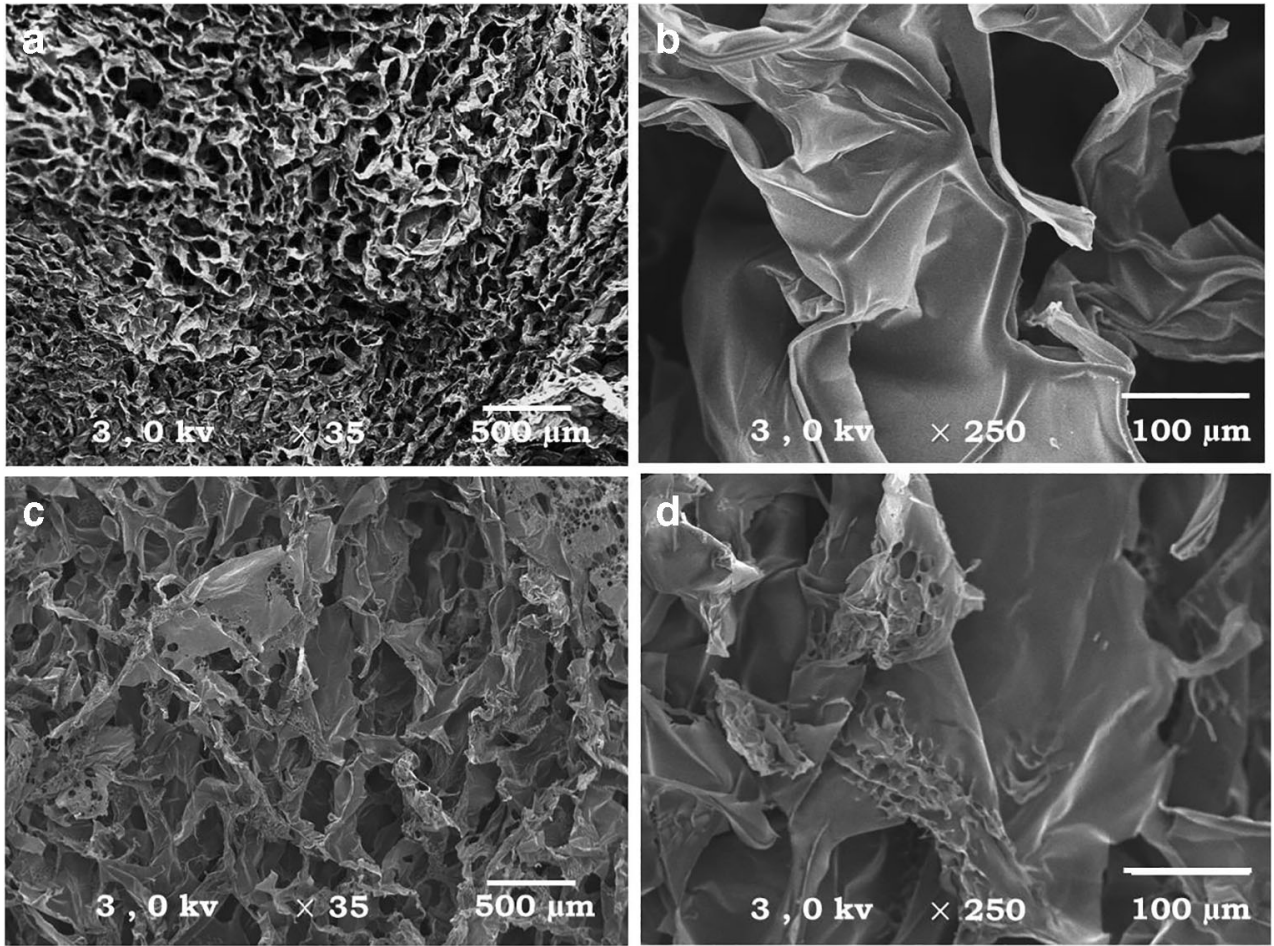

(negative control $(p<0.05)$ and such effect was shown not to be related to the otolith's incorporation as otoliths did not impair the cell viability. However, it might be a result of some products generated from the interaction between otoliths and sodium alginate molecules. This interaction seems to occur due to the probable substitution of sodium ions $\left(\mathrm{Na}^{+}\right)$, from the sodium alginate, by calcium $\left(\mathrm{Ca}^{2+}\right)$, from the calcium carbonate present in the otoliths. Thus, it is possible that the replacement and crosslinking reaction of the molecule could determine $\mathrm{CO}_{3}{ }^{-2}$ formation. This could have led to the mild reduction in cell viability observed in the current study, since carbonate anion formation has been previously reported to induce oxidative stress in cell culture [35]. This possibility also seems to be supported by our previous FTIR data, which showed greater interaction between the otoliths and the alginate molecules, probably via calcium carbonate interacting with the oxygen of the $\mathrm{C}=\mathrm{O}$ bonds. However, only high concentrations of calcium carbonate can promote substantial changes in the cell viability profile [36], which was also observed in the current study, as cell viability after treatment with ALG/OTL-s was $80.3 \pm 2.1 \%$, considered appropriate to tissue engineering.

As shown in Fig. 8, the growth of MC3T3-E1 cells treated with ALG/OTL-s and GEL/OTL-s scaffolds was statistically similar to the control group in $24 \mathrm{~h}(p>0.05)$. However, at $48 \mathrm{~h}$, osteoblast viability in ALG/OTL-s was similar to the control $(p>0.05)$, but significantly lower in GEL/OTL-s $(p<0.05)$. These data suggest that sodium alginate-based scaffolds provided a better matrix for osteoblast growth than gelatin. Although the reasons for the best performance of ALG/OTL-s are not fully clarified, it is possible that the low levels of free $\mathrm{CO}_{3}{ }^{-2}$ released from the interaction of the calcium carbonate from otoliths and sodium of alginate chain might have increased the $\mathrm{pH}$ of the medium, and alkaline PH has been previously demonstrated to enhance osteoblast metabolic activity and viability [13]. However, further studies are still necessary to prove this theory right.

This study demonstrated the successful development of scaffolds that exhibited porous 3D architecture that can favor cell fixation, proliferation, and differentiation for bone engineering applications. Besides, taken together, the results suggest that the ALG/OTL scaffolds would represent more suitable materials for applications such as biomaterials in bone tissue engineering, as they present a better morphological structure for cell migration, present a cytocompatibility profile considered fully acceptable in J774.G8 cells, and promote greater growth of osteoblasts (MC3T3-E1 cells) after $48 \mathrm{~h}$, in comparison with the GEL/OTL scaffolds. However, it is well-established that the nanometric size of the inorganic particle has a notable effect on improving the mechanical properties of the scaffold and is considered critical for an excellent dispersion of the particle within the polymeric matrix [32]. For this reason, a detailed study about the impact of the morphology and particle size of otoliths on the biological functions of the otoliths-incorporated nanocomposites is still necessary in order to optimize its use as a biomineral and improve the adhesion, proliferation, and differentiation of osteoblastic cells. 
Fig. 6 SEM photomicrographs of the structure of otoliths presenting rectangular, polyhedral, or cuboid crystals, with an irregular surface $(\mathbf{a}, \mathbf{b})$. Small crystals of variable diameter compatible with otoliths micro-fragments homogeneously distributed along the walls of the 3D structure of GEL/OTL-s $(\mathbf{c}, \mathbf{d})$ and ALG/OTL-s (e, f)
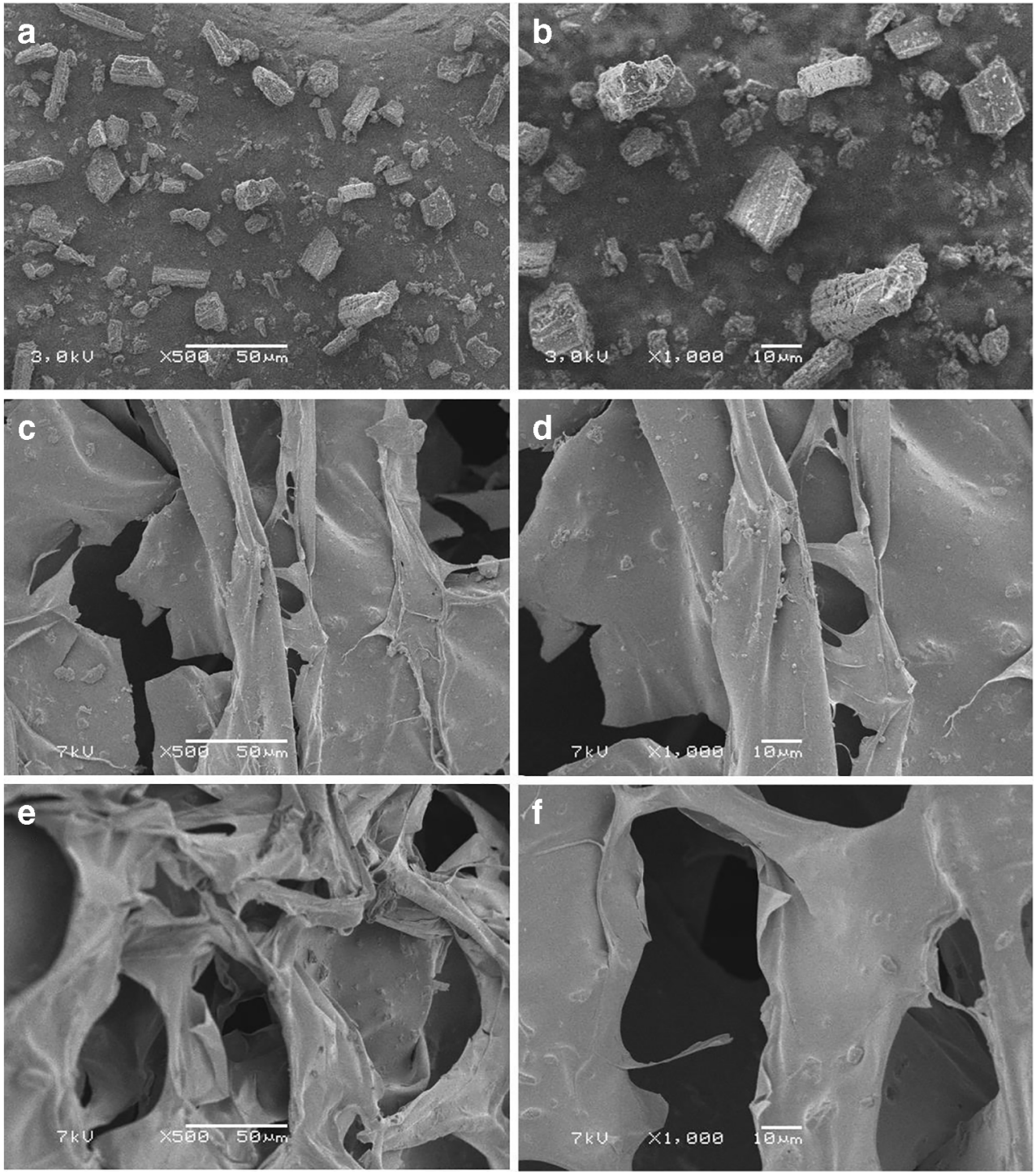

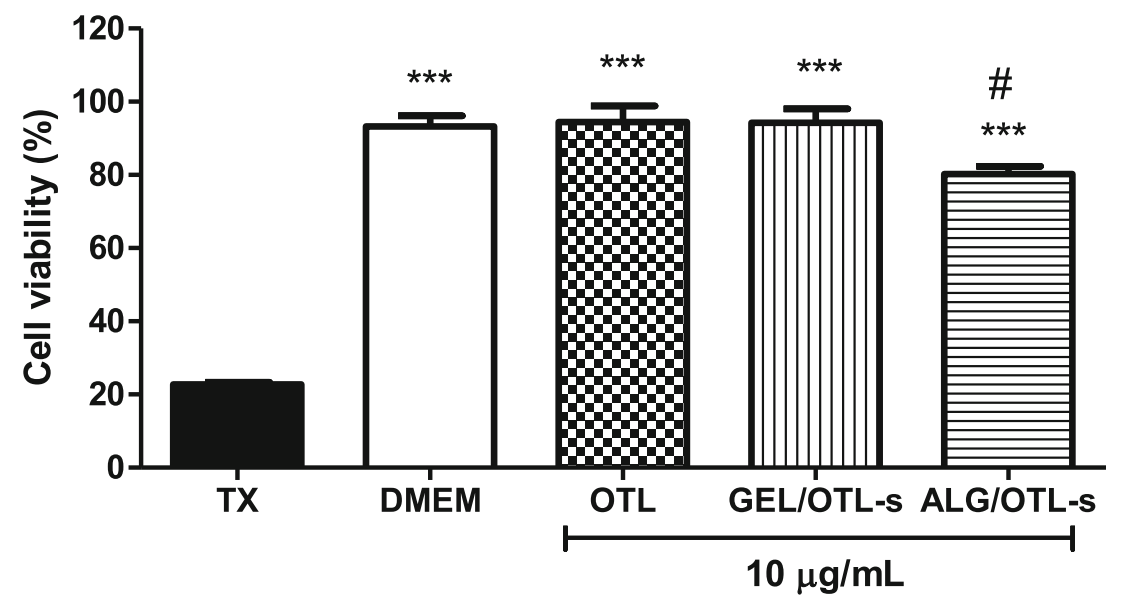

Fig. 7 Assessment of cytotoxicity of the otoliths (OTL) and otolithincorporated gelatin and sodium alginate scaffolds (GEL/OTL-s and ALG/OTL-s) using macrophage lineage J774.G8 cells. Data are expressed as mean \pm standard mean error. Significant differences in

relation to Triton-X (TX) are expressed as $* * * p<0.001$; and in relation to DMEM is expressed as ${ }^{\#} p<0.05$ (ANOVA and multiple comparisons Tukey's test) 
Fig. 8 Assessment of cytotoxicity of the otoliths (OTL) and otolithincorporated gelatin and sodium alginate scaffolds (GEL/OTL-s and ALG/OTL-s) using osteoblast lineage MC3T3-E1 cells. Data are expressed as mean \pm standard mean error. Significant differences in relation to control are expressed as $* p<0.05$ (twoway ANOVA and multiple comparisons of Tukey's test)

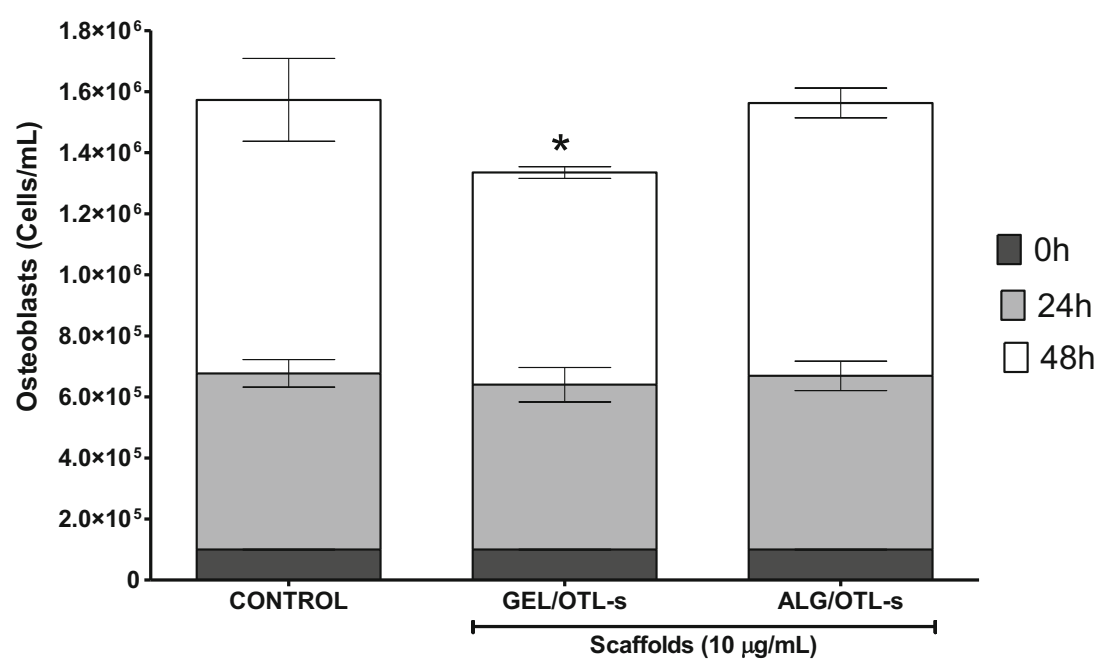

\section{Conclusions}

The method of particle aggregation used in this study was successful for the formation of 3D spongy scaffolds of gelatin and sodium alginate containing otolith particles (GEL/OTL and ALG/OTL, respectively), with interaction between the otoliths and the polymeric matrices. Although our data suggest that both scaffolds may be promising alternatives to mimic the natural mineral and organic phases of bone tissue, ALGOTL scaffolds presented larger and more homogeneous and interconnected pores in comparison with GEL/OTL, as well as biocompatibility with macrophage (J774.G8 cells), and provided higher osteoblast (MC3T3-E1 cells) growth in vitro. Therefore, ALG/OTL-s scaffolds may work as attractive substitutes for bone graft and tissue regeneration in tissue engineering.

Author contribution statement Conceptualization: Daisy Pereira Valido. Methodology: Wilson Déda Gonçalves Júnior, Maria Eliane de Andrade, Allan Andrade Rezende, Felipe Mendes de Andrade de Carvalho, Renata de Lima, Gabriela das Graças Gomes Trindade, Caio de Alcântara Campos, Ana Maria Santos Oliveira, Eloísa Portugal Barros Silva Soares de Souza, Luiza Abrahão Frank. Formal analysis and investigation: Silvia Stanisçuaski Guterres. Writing - original draft preparation: Eliana Midori Sussuchi, Charlene Regina Santos Matos, André Polloni, Adriano Antunes de Souza Araújo, Patrícia Severino. Writing - review and editing: Eliana Barbosa Souto. Funding acquisition: Francine Ferreira Padilha, Supervision: Ricardo Luiz Cavalcanti de Albuquerque Júnior.

Funding We would like to thank the National Council for Scientific and Technological Development (CNPq) and the Foundation for Research and Technological Innovation Support of the State of Sergipe for the financial support in this study. EMBS acknowledges the sponsorship of the projects M-ERA-NET-0004/2015-PAIRED and UIDB/04469/2020 (strategic fund), received support from the Portuguese Science and Technology Foundation, Ministry of Science and Education (FCT/ MEC) through national funds, and was co-financed by FEDER, under the Partnership Agreement PT2020.

\section{Compliance with ethical standards}

Conflict of interest The authors declare that they have no conflict of interest.

\section{References}

1. Ghassemi T, Shahroodi A, Ebrahimzadeh MH, Mousavian A, Movaffagh J, Moradi A. Current concepts in scaffolding for bone tissue engineering. Arch Bone Jt Surg. 2018;6(2):90-9.

2. Orshesh Z, Borhan S, Kafashan H. Physical, mechanical and in vitro biological evaluation of synthesized biosurfactantmodified silanated-gelatin/sodium alginate/45S5 bioglass bone tissue engineering scaffolds. J Biomater Sci Polym Ed. 2020;31(1): 93-109. https://doi.org/10.1080/09205063.2019.1675226.

3. Kolbuk D, Heljak M, Choinska E, Urbanek O. Novel 3D hybrid nanofiber scaffolds for bone regeneration. Polymers (Basel). 2020;12(3). https://doi.org/10.3390/polym12030544.

4. Lv J, Liu W, Shi G, Zhu F, He X, Zhu Z, et al. Human cardiac extracellular matrix-chitosan-gelatin composite scaffold and its endothelialization. Exp Ther Med. 2020;19(2):1225-34. https://doi. org/10.3892/etm.2019.8349.

5. Cheng CH, Lai YH, Chen YW, Yao CH, Chen KY. Immobilization of bone morphogenetic protein-2 to gelatin/avidin-modified hydroxyapatite composite scaffolds for bone regeneration. J Biomater Appl. 2019;33(9):1147-56. https://doi.org/10.1177/ 0885328218820636.

6. Narayanaswamy R, Torchilin VP. Hydrogels and their applications in targeted drug delivery. Molecules. 2019;24(3):603. https://doi. org/10.3390/molecules24030603.

7. Izzo C, Doubleday ZA, Gillanders BM. Where do elements bind within the otoliths of fish? \%J. Mar Freshw Res. 2016;67(7):10726. https://doi.org/10.1071/MF15064.

8. Weigele J, Franz-Odendaal TA, Hilbig R. Spatial expression of otolith matrix protein-1 and otolin-1 in normally and kinetotically swimming fish. Anat Rec. 2015;298(10):1765-73. https://doi.org/ 10.1002/ar.23184.

9. Murayama E, Takagi Y, Ohira T, Davis JG, Greene MI, Nagasawa H. Fish otolith contains a unique structural protein, otolin-1. Eur J Biochem. 2002;269(2):688-96. https://doi.org/10.1046/j.00142956.2001.02701.x. 
10. Murayama E, Takagi Y, Nagasawa H. Immunohistochemical localization of two otolith matrix proteins in the otolith and inner ear of the rainbow trout, Oncorhynchus mykiss: comparative aspects between the adult inner ear and embryonic otocysts. Histochem Cell Biol. 2004;121(2):155-66. https://doi.org/10.1007/s00418-0030605-5.

11. De Olyveira GM, Valido DP, Costa LMM, Gois PBP, Xavier-Filho L, Basmaji P. Otoliths/collagen/bacterial cellulose nanocomposites as a potential scaffold for bone tissue regeneration. J Biomater Nanobiotechnol. 2011;2:239-43. https://doi.org/10.4236/jbnb. 2011.23030.

12. Orimo $\mathrm{H}$. The mechanism of mineralization and the role of alkaline phosphatase in health and disease. J Nippon Med Sch. 2010;77(1): 4-12. https://doi.org/10.1272/jnms.77.4.

13. Galow A-M, Rebl A, Koczan D, Bonk SM, Baumann W, Gimsa J. Increased osteoblast viability at alkaline $\mathrm{pH}$ in vitro provides a new perspective on bone regeneration. Biochem Biophys Rep. 2017;10: 17-25. https://doi.org/10.1016/j.bbrep.2017.02.001.

14. Dawson ER, Suzuki RK, Samano MA, Murphy MB. Increased internal porosity and surface area of hydroxyapatite accelerates healing and compensates for low bone marrow mesenchymal stem cell concentrations in critically-sized bone defects. Applied Sci 2018;8(8):1366

15. Lebre F, Sridharan R, Sawkins MJ, Kelly DJ, O’Brien FJ, Lavelle EC. The shape and size of hydroxyapatite particles dictate inflammatory responses following implantation. Sci Rep. 2017;7(1):2922. https://doi.org/10.1038/s41598-017-03086-0.

16. Cavalcante AM, Lima JCS, Santos LM, Oliveira PCC, Ribeiro Júnior KAL, Sant'ana AEG. Comparative evaluation of the $\mathrm{pH}$ of calcium hydroxide powder in contact with carbon dioxide (CO2). $\mathrm{J}$ Mater Res. 2010;13:1-4.

17. Zhang D, Wu X, Chen J, Lin K. The development of collagen based composite scaffolds for bone regeneration. Bioactive Mater. 2018;3(1):129-38. https://doi.org/10.1016/j.bioactmat.2017.08. 004.

18. Yu W, Sun T-W, Qi C, Ding Z, Zhao H, Zhao S, et al. Evaluation of zinc-doped mesoporous hydroxyapatite microspheres for the construction of a novel biomimetic scaffold optimized for bone augmentation. Int J Nanomedicine. 2017;12:2293-306. https://doi.org/ 10.2147/IJN.S126505.

19. Dongni R, Yonghua G, Qingling F. Comparative study on nanomechanics and thermodynamics of fish otoliths. Mater Sci Eng C Mater Biol Appl. 2013;33(1):9-14. https://doi.org/10.1016/j.msec. 2012.07.023.

20. Kavoosi G, Derakhshan M, Salehi M, Rahmati L. Microencapsulation of zataria essential oil in agar, alginate and carrageenan. Innovative Food Sci Emerg Technol. 2018;45:41825. https://doi.org/10.1016/j.ifset.2017.12.010.

21. Shehap AM, Mahmoud K, El-Kader MFA, El-Basheer TM. Preparation and thermal properties of gelatin/TGS composite films. Middle East J Appl Sci. 2015;5:157-70.

22. Dong Y, Dong W, Cao Y, Han Z, Ding Z. Preparation and catalytic activity of $\mathrm{Fe}$ alginate gel beads for oxidative degradation of azo dyes under visible light irradiation. Catal Today. 2011;175(1):34655. https://doi.org/10.1016/j.cattod.2011.03.035.

23. Liu Y, Zhou Y, Jiang T, Liang YD, Zhang Z, Wang YN. Evaluation of the osseointegration of dental implants coated with calcium carbonate: an animal study. Int J Oral Sci. 2017;9(3):133-8. https:// doi.org/10.1038/ijos.2017.13.
24. De Souza SPMC, de Morais FE, dos Santos EV, Martinez-Huitle CA, Fernandes NS. Determination of calcium content in tablets for treatment of osteoporosis using thermogravimetry (TG). J Therm Anal Calorim. 2011;111(3):1965-70. https://doi.org/10.1007/ s10973-011-2119-z

25. Montañez-Supelano ND, Estupiñan-Durán HA, García SJ, PeñaBallesteros DY. Fabrication and characterization of novel biphasic calcium phosphate and nanosized hydroxyapatite derived from fish otoliths in different composition ratios. Chem Eng Trans. 2018;64: 307-12. https://doi.org/10.3303/CET1864052.

26. Mirzaei B, Etemadian S, Goli HR, Bahonar S, Gholami SA, Karami $\mathrm{P}$, et al. Construction and analysis of alginate-based honey hydrogel as an ointment to heal of rat burn wound related infections. Int $\mathbf{J}$ Burns Trauma. 2018;8(4):88-97.

27. Poddar S, Agarwal PS, Sahi AK, Vajanthri KY, Pallawi, Singh KN, et al. Fabrication and cytocompatibility evaluation of psyllium husk (Isabgol)/gelatin composite scaffolds. Appl Biochem Biotechnol. 2019;188(3):750-68. https://doi.org/10.1007/s12010-019-029587.

28. Nezhadi SH, Choong PF, Lotfipour F, Dass CR. Gelatin-based delivery systems for cancer gene therapy. J Drug Target. 2009;17(10):731-8. https://doi.org/10.3109/10611860903096540.

29. Verma V, Verma P, Kar S, Ray P, Ray AR. Fabrication of agargelatin hybrid scaffolds using a novel entrapment method for in vitro tissue engineering applications. Biotechnol Bioeng. 2007;96(2):392-400. https://doi.org/10.1002/bit.21111.

30. Pan T, Song W, Cao X, Wang Y. 3D bioplotting of gelatin/alginate scaffolds for tissue engineering: influence of crosslinking degree and pore architecture on physicochemical properties. J Mater Sci Technol. 2016;32(9):889-900. https://doi.org/10.1016/j.jmst.2016. 01.007.

31. Yang H, Zhao X, Xu Y, Wang L, He Q, Lundberg YW. Matrix recruitment and calcium sequestration for spatial specific otoconia development. PLoS One. 2011;6(5):e20498. https://doi.org/10. 1371/journal.pone.0020498.

32. Abdal-hay A, Khalil KA, Hamdy AS, Al-Jassir FF. Fabrication of highly porous biodegradable biomimetic nanocomposite as advanced bone tissue scaffold. Arab J Chem. 2017;10(2):240-52. https://doi.org/10.1016/j.arabjc.2016.09.021.

33. Gentile P, Nandagiri VK, Daly J, Chiono V, Mattu C, Tonda-Turo $\mathrm{C}$, et al. Localised controlled release of simvastatin from porous chitosan-gelatin scaffolds engrafted with simvastatin loaded PLGA-microparticles for bone tissue engineering application. Mater Sci Eng C Mater Biol Appl. 2016;59:249-57. https://doi. org/10.1016/j.msec.2015.10.014.

34. Rezwan K, Chen QZ, Blaker JJ, Boccaccini AR. Biodegradable and bioactive porous polymer/inorganic composite scaffolds for bone tissue engineering. Biomaterials. 2006;27(18):3413-31. https://doi. org/10.1016/j.biomaterials.2006.01.039.

35. Dizaj SM, Barzegar-Jalali M, Zarrintan MH, Adibkia K, Lotfipour F. Calcium carbonate nanoparticles; potential in bone and tooth disorders. Pharm Sci. 2015;20(3):175-82.

36. Kamba AS, Ismail M, Ibrahim TA, Zakaria ZA. Biocompatibility of bio based calcium carbonate nanocrystals aragonite polymorph on NIH 3 T3 fibroblast cell line. Afr JTradit Complement Altern Med. 2014;11(4):31-8. https://doi.org/10.4314/ajtcam.v11i4.5.

Publisher's note Springer Nature remains neutral with regard to jurisdictional claims in published maps and institutional affiliations. 


\section{Affiliations}

Daisy Pereira Valido ${ }^{1,2} \cdot$ Wilson Déda Gonçalves Júnior ${ }^{1,2} \cdot$ Maria Eliane de Andrade $^{1,2} \cdot$ Allan Andrade Rezende $^{1,2}$. Felipe Mendes de Andrade de Carvalho ${ }^{1,2} \cdot$ Renata de Lima $^{3} \cdot$ Gabriela das Graças Gomes Trindade $^{4}$.

Caio de Alcântara Campos ${ }^{4}$. Ana Maria Santos Oliveira ${ }^{4}$ Eloísa Portugal Barros Silva Soares de Souza ${ }^{4}$.

Luiza Abrahão Frank ${ }^{5}$. Silvia Stanisçuaski Guterres ${ }^{5}$. Eliana Midori Sussuchi ${ }^{4}$. Charlene Regina Santos Matos ${ }^{4}$. André Polloni $^{1,2}$. Adriano Antunes de Souza Araújo ${ }^{4}$. Francine Ferreira Padilha ${ }^{1,2}$ • Patrícia Severino ${ }^{1,2,6,7}$ (D)

Eliana Barbosa Souto ${ }^{8,9}$. Ricardo Luiz Cavalcanti de Albuquerque Júnior ${ }^{1,2}$

1 Tiradentes University, Av. Murilo Dantas, 300, Aracaju 49010-390, Brazil

2 Laboratory of Nanomedicine and Nanotecnology, Instituto de Tecnologia e Pesquisa, Av. Murilo Dantas, 300 - Farolândia, Aracaju, SE 49032-490, Brazil

3 Department of Biotechnology, University of Sorocaba, Rodovia Raposo Tavares S/N-km 92,5, Sorocaba, SP CEP 18023-000, Brazil

4 Department of Physiology, Federal University of Sergipe, São Cristóvão, Sergipe 49100-00, Brazil

5 Faculty of Pharmacy, Federal University of Rio Grande do Sul, Av. Ipiranga, 2759, Porto Alegre, Rio Grande do Sul 90610-000, Brazil
6 Tiradentes Institute, 150 Mt Vernon St, Dorchester, MA 02125, USA

7 Center for Biomedical Engineering, Department of Medicine, Brigham and Women's Hospital, Harvard Medical School, 65 Landsdowne Street, Cambridge, MA 02139, USA

8 Faculty of Pharmacy, University of Coimbra, Pólo das Ciências da Saúde, Azinhaga de Santa Comba, 3000-548 Coimbra, Portugal

9 CEB - Centre of Biological Engineering, University of Minho, Campus de Gualtar, 4710-057 Braga, Portugal 